LOS

ANGELES

CONTRIBUTION

COUNTY

MUSEUM

OBSERVATIONS ON CAPTIVE AND WILD ATLANTIC BOTTLENOSED DOLPHINS, TURSIOPS TRUNCATUS, IN THE NORTHEASTERN GULF OF MEXICO

by Melba C. Caldwell, David K. Caldwell and J. B. Siebenaler 
CONTRIBUTIONS IN SCIENCE is a series of miscellaneous technical papers in the fields of Biology, Geology and Anthropology, published at irregular intervals by the Los Angeles County Museum. Issues are numbered separately, and numbers run consecutively regardless of subject matter. Number 1 was issued January 23, 1957. The series is available to scientists and scientific institutions on an exchange basis. Copies may also be purchased at a nominal price.

\section{INSTRUCTIONS FOR AUTHORS}

Manuscripts for the LOS ANGELES COUNTY MUSEUM CONTRIBUTIONS IN SCIENCE may be in any field of Life or Earth Sciences. Acceptance of papers will be determined by the amount and character of new information and the form in which it is presented. Priority will be given to manuscripts by staff members, or to papers dealing with specimens in the Museum's collections. Manuscripts must conform to CONTRIBUTIONS style and will be examined for suitability by an Editorial Committee. They may also be subject to critical review by competent specialists.

MANUSCRIPT FORM.-(1) The 1960 AIBS Style Manual for Biological Journals is highly recommended as a guide. (2) Typewrite material, using double spacing throughout and leaving ample margins, on only one side of $81 / 2 \times 11$ inch standard weight paper. (3) Place tables on separate pages. (4) Footnotes should be avoided if possible. (5) Legends for figures and unavoidable footnotes should be typed on separate sheets. Several of one kind may be placed on a sheet. (6) Method of literature citation must conform to CONTRIBUTIONS style-see number 50 and later issues. Spell out in full the title of non-English serials and places of publication. (7) A factual summary is recommended for longer papers. (8) A brief abstract should be included for all papers. This will be published at the head of each paper.

ILLUSTRATIONS.-All illustrations, including maps and photographs, should be referred to as "figures." All illustrations should be of sufficient clarity and in the proper proportions for reduction to CONTRIBUTIONS page size. Permanent ink should be used in making line drawings and in lettering (do not type on drawings); photographs should be glossy prints of good contrast. Original illustrations will not be returned unless specifically requested when the manuscript is first submitted. Authors may also request their engravings at this time.

PROOF.-Authors will be sent galley proof which should be corrected and returned promptly. Changes after the paper is in galley will be billed to the author. Unless specially requested, page proof will not be sent to the author. 100 copies of each paper will be given free to a single author or divided equally among multiple authors. Orders for additional copies should be sent to the Editor at the time corrected galley proof is returned; appropriate forms for this will be included when galley is sent.

\section{DAVid K. CALDWELL}

Editor 


\title{
OBSERVATIONS ON CAPTIVE AND WILD ATLANTIC BOTTLENOSED DOLPHINS, TURSIOPS TRUNCATUS, IN THE NORTHEASTERN GULF OF MEXICO ${ }^{1}$
}

\author{
By Melba C. Caldwell, ${ }^{2}$ David K. Caldwell ${ }^{3}$ and J. B. Siebenaler ${ }^{4}$
}

\begin{abstract}
Data are presented concerning scouting behavior by wild specimens; learning by observation by captive animals; directional swimming of captives; evidence for stress-caused ulcers in captive specimens; ingestion of foreign objects by both captive and wild cetaceans; seasonal micro-distribution of wild animals; and a shark bite and infestations of the whale barnacle Xenobalanus globicipitus on wild specimens. Included also are additional records for the pigmy sperm whale, Kogia breviceps, and Cuvier's beaked whale, Ziphius cavirostris, in the northeastern Gulf of Mexico.
\end{abstract}

The present knowledge concerning the ecology and behavior of cetaceans is still distressingly incomplete, even for a species as much studied as the Atlantic bottlenosed dolphin, Tursiops truncatus (Montagu). Because we have accumulated a number of fragmentary observations on this species from observations in the wild and during the procedures of capture, training and subsequent captive existence at Florida's Gulfarium, Fort Walton Beach, which seem to contribute to a better understanding of its biology, we take this opportunity to record them here. The observations are naturalistic and opportunistic, but they point the way in some cases for possible experimental procedures, and it may never be possible to investigate some of these behaviors further in the laboratory under any conditions.

Observations on scouting behavior by wild TURSIOPS TRUNCATUS: One instance of scouting of a barrier in the open ocean has previously been reported for Tursiops gilli Dall (Eberhardt and Evans, 1962:326; Evans and Dreher, 1962:220; Dreher and Evans, 1964:383). Their findings report the detachment of a scout from a school. The scout made several echolocation runs on an artificial barrier, each time returning to the group after the run. As the barrier was passable at one end, the school finally avoided the barrier and continued on its way.

${ }^{1}$ Partial support for certain phases of this study was received through grants from the National Institute of Mental Health (MH-07509-01) and the National Science Foundation (GB-1189).

${ }^{2}$ Research Associate, Los Angeles County Museum, also University of Southern California, Antarctic Research Program.

${ }^{3}$ Curator of Ichthyology, Los Angeles County Museum: also Research Associate, Florida State Museum, and Collaborator in Ichthyology, Institute of Jamaica.

${ }^{4}$ Curator and General Manager, Florida's Gulfarium, Fort Walton Beach, Florida. 
Additional data on scouting behavior is available from the capture proceedings of Tursiops truncatus near Fort Walton Beach and Destin, Florida. At one time the practice at the Gulfarium was to catch a school of dolphins in one of the many dead-end bays in the area. These bays were ones with a narrow mouth and shallow water. A net was strung completely across the mouth of the bay after a school of dolphins had entered. The second largest male (sexes were determined after the animals were captured; individuals were identified by marks and fin shapes), which came to be called by the fishermen the "Lieutenant", detached himself from the group and scouted the net. He then returned to the group. Following this, the largest male, closely followed by a large female, charged the net. Sometimes this procedure was successful and the group followed them through the opening, either a break in the net caused by the charge, or a spot where the top of the net was pulled down by the charge. Usually, however, the entire school could be captured. Only rarely did an animal leap over the net. Also, in a former North Carolina fishery, $T$. truncatus were taken commercially by net. It was said that they rarely jumped the net when encircled, but if one did, the others followed (Clark, 1887:309). Net scouting behavior by $T$. truncatus during capture attempts on the east coast of Florida was also suggested by remarks made in a popular account (Chapin, 1962:26). Present capture procedure at the Gulfarium includes encircling schools of dolphins either in open water or from the open beach. Although the scouting behavior is not as easy to observe under these circumstances, it often does occur.

Evidence for learning by observation by captive TURSIOPS TRUNCATUS: Learning by observation rarely has been shown in animal groups other than man (Beach, 1947). Chimpanzees do, however, learn faster if permitted to observe problem solving from experienced chimpanzees (Crawford and Spence, 1939; Darby and Riopelle, 1959). Also, monkeys have learned a new habit of washing sweet potatoes before eating by observing a young member of their group perform this unusual behavior (Miyadi, 1959:859).

At the Gulfarium, naive animals are placed in tanks with trained animals. These untrained animals are back-up performers for the trained dolphins, and the training period for the back-up animals is considerably reduced by this procedure.

One striking example of this learning by observation occurred at the Gulfarium. A dolphin was used to begin the show by raising a flag. This was done by training the animal to leap, grasp and pull a ball suspended over the water. This trained animal was sent away and a fresh animal was trained to perform the act. However, the trainer erred slightly and the new dolphin was conditioned in such a way that it learned to leap and raise the flag by striking the ball with its snout, instead of grasping it in its teeth as it was supposed to do. This animal later died, and another female, "Belinda," a tank mate and backup animal for the animal that was incorrectly trained, took over the act immediately and without training. Furthermore, she performed the trick by the 
same incorrect procedure of striking the ball with her snout instead of grasping it. Belinda was then trained to perform the act correctly by seizing the ball and this became a part of the show.

An additional prop, a flash camera, was subsequently installed on the flag-raising apparatus. This new prop frightened Belinda, and she refused to perform. However, a young male that had been in the tank for eight months took over for the two performances that Belinda missed, flashing the camera by seizing and pulling the ball. The young male's previous training had consisted solely of being taught to play basketball, an entirely unrelated trick. After the two shows, Belinda resumed her old place in the act after her initial fear of the new prop was abated.

Directional swimming by captive cetaceans: For a period of about 10 years, from 1954 until the winter of 1964, all of the newly-introduced $T$. truncatus at the Gulfarium swam counter-clockwise, regardless of the direction of the current flow in the tanks. Charles Emmett of the Aquarium of Niagara Falls, New York, and Donald McSheehey of the Aquatarium, St. Petersburg, Florida, also reported this same experience (pers. conver., with Siebenaler). However, out of seven animals captured in the winter of 1964, and observed at the Gulfarium or by Marjorie Siebenaler elsewhere at Fort Walton Beach, six swam clockwise and only one counter-clockwise. McSheehey (pers. conver., 1965, with Siebenaler) also stated that, contrary to his past experience, two dolphins captured on 1 April 1965 swam clockwise. We have no explanation for this behavioral change as the locations of capture have not been changed.

To further complicate the picture, all of the freshly-introduced $T$. truncatus (from Florida) that we observed during studies at Marineland of the Pacific, near Los Angeles, swam in a clockwise direction.

Through 1964, only counter-clockwise swimming was performed at the Gulfarium by several captive spotted dolphins, Stenella plagiodon (Cope), held at different times, and by a captive adult male pigmy sperm whale, Kogia breviceps (Blainville), which stranded near Fort Walton Beach several years ago. The latter animal apparently constitutes the sixth record for this species in the Gulf of Mexico (see Caldwell, Inglis and Siebenaler, 1960).

Evidence for ulcers caused by stress in captive animals: Unusual psychological stress can have dire effects on captive dolphins. In the early period during 1957 when the Gulfarium was open to the public but still not fully structurally complete, the seawater system of the main dolphin tank was being reworked and additions being made. For several weeks the animals were subjected to a constant barrage of pounding on the attached water pipes. The noise was deafening to human divers working underwater in the tank at times when this was happening. Consequently it must have been even more disturbing to the sensitive auditory apparatus of the dolphins. Shortly thereafter, about six of the dolphins died. Autopsy by a local veterinarian and a local medical doctor, and corroborated by the Gulfarium biologists, revealed the probable cause 
of death of all of the dolphins to be duodenal ulcers. There was no question, at least, that the ulcers were present and severe. Brown and Norris (1956:320) cited a case of death in a captive Pacific common dolphin, Delphinus bairdi Dall, due to a perforated gastric ulcer. They attributed the perforation to a refusal to feed because of the death of another animal to which the dolphin was closely attached. Brown and Norris also reported two cases of healed gastric ulcers in two D. bairdi that were autopsied in the laboratory.

In the fall of 1964, an adult male $T$. truncatus died at the Gulfarium after spending several years in captivity there; first arriving as a very young animal. This animal became somewhat of a pet, but had undergone intermittent training for the show and at times had performed certain trained acts in the main show tank. When not in the show tank, he was kept in a small training tank, sometimes in isolation from other dolphins, sometimes not. When in the main show tank, particularly during the last year of his life, he had received rather rough treatment by the larger females. Upon autopsy, he was found to have perforated gastric ulcers which, it was postulated, contributed to his death if it was not the actual cause.

Ingestion of foreign objects by captive and wild cetaceans: Captive dolphins are prone to ingest all manner of inedible objects (Brown, et al., 1960). Stomach contents of autopsied animals at the Gulfarium include gravel, metal nuts, coins (including one as small as a dime), a lady's broach, and plastic stripping from the inside of the tanks. The stripping measured up to 18 inches long and two to three inches wide.

This inclination to ingest such items as the plastic stripping led to a catastrophic mass mortality among the Gulfarium's trained show animals during the latter part of November, 1964. Through a series of unfortunate circumstances, two of the main show animals, an adult male and female, and an adult female back-up animal all ingested large quantities of this stripping and died. Balls of the plastic up to four inches in diameter were found impacted in the first stomach of these animals. In one instance the stomach, normally five to six inches in diameter, was distended to nearly 12 inches with the impacted balls of plastic. Another animal, an adult female, was saved when the trainers forced her to regurgitate the contents of her stomach after a liberal dose of mineral oil. This animal regurgitated nearly ten quarts of the balls of plastic and, in addition, an 8-inch lady's comb.

Such seemingly perverse ingestion is not confined to captive dolphins. Petit, Lomont and Theodorides (1956) found fragments of both marine and terrestrial plants, including wood, foliage from a plantain, black poplar foliage, palm foliage and root stock (all in the total amount of 780 grams) impacted in the anterior stomach of a wild specimen reported as Tursiops tursio Fabr. Mr. Robert L. Brownell, Jr., stated (pers. conversation, 1965) that he once found a piece of paper wadded into a two-inch ball, along with seaweed, squid beaks and roundworms, in the stomach of a 5.5-foot male Pacific striped dolphin, Lagenorhynchus obliquidens Gill. The animal had stranded alive at 
the Santa Monica pier, California, on 29 August 1963. A wide variety of inedible objects also has been recovered from the stomachs of wild sperm whales, Physeter catodon Linnaeus; the list includes rocks, sand, a glass fishing buoy, a coconut, wood, an apple, a shoe, a plastic bag and bailing wire (Caldwell, Caldwell and Rice, 1965).

Seasonal micro-distribution of TURSIOPS TRUNCATUS: While these dolphins are present in the Fort Walton Beach-Destin area in Florida throughout the year, there is a definite tendency for seasonal variation in microhabitat in that region.

During the winter, from December to mid-March, these dolphins move far up into the shallow bayous which constitute the headwaters of Choctawhatchee Bay. The waters of these bayous are fresh at these times, and the dolphins apparently are there feeding on small clupeid fishes that spawn there at that time and on sea trout (Cynoscion). During this period in the bayous, the dolphins develop eruptions on their skin which are like those which develop when these animals are kept captive in fresh water for several weeks. This suggests, therefore, that the animals do not move in and out of the bayous into salt water, but instead remain in them for extended periods.

During the rest of the year, Tursiops are found in the deep passes between the bay and the open Gulf, and in and just behind the surf zone along the open beach and up to a mile or so offshore.

There is almost no exception to these seasonal distributions, and dolphins are absent from the bayous in summer and absent from the passes and beaches in winter.

Infestations of the cosmopolitan obligate cetacean barnacle, XENOBALANUS GLOBICIPITUS Steenstrup: Although the list of hosts for this unusual barnacle is long, we have found but one reference (Barnard, 1924:96) listing it from a species of Tursiops. The host was reported as $T$. catalaniae (Gray) from Natal.

A school of six adults and two young T. truncatus was captured on 30 June 1964 just off East Pass, near Destin. The two unweaned young, a 51-inch male and an 80-inch female, each with milk in their stomachs, had a massive infestation of these barnacles attached along the entire posterior part of their caudal flukes and a few of the barnacles attached near the distal tips of the dorsal and both pectoral flippers. The barnacles on the caudal flukes were most abundant on the dorsal surface, covering an area up to three inches from the posterior edge of the flukes, as well as covering the posterior edge itself. None of the adults from the school were infested.

Siebenaler has seen these barnacles on other $T$. truncatus, including adults, caught in the vicinity of Destin over a period of nearly ten years. Mr. F. G. Wood, presently of the Naval Ordinance Test Center at Point Mugu, California, told us (in late 1964) that he had seen these barnacles on Atlantic bottlenosed dolphins collected on the upper east coast of Florida. At Point Mugu, through the courtesy of Dr. Sam H. Ridgway, we saw additional speci- 


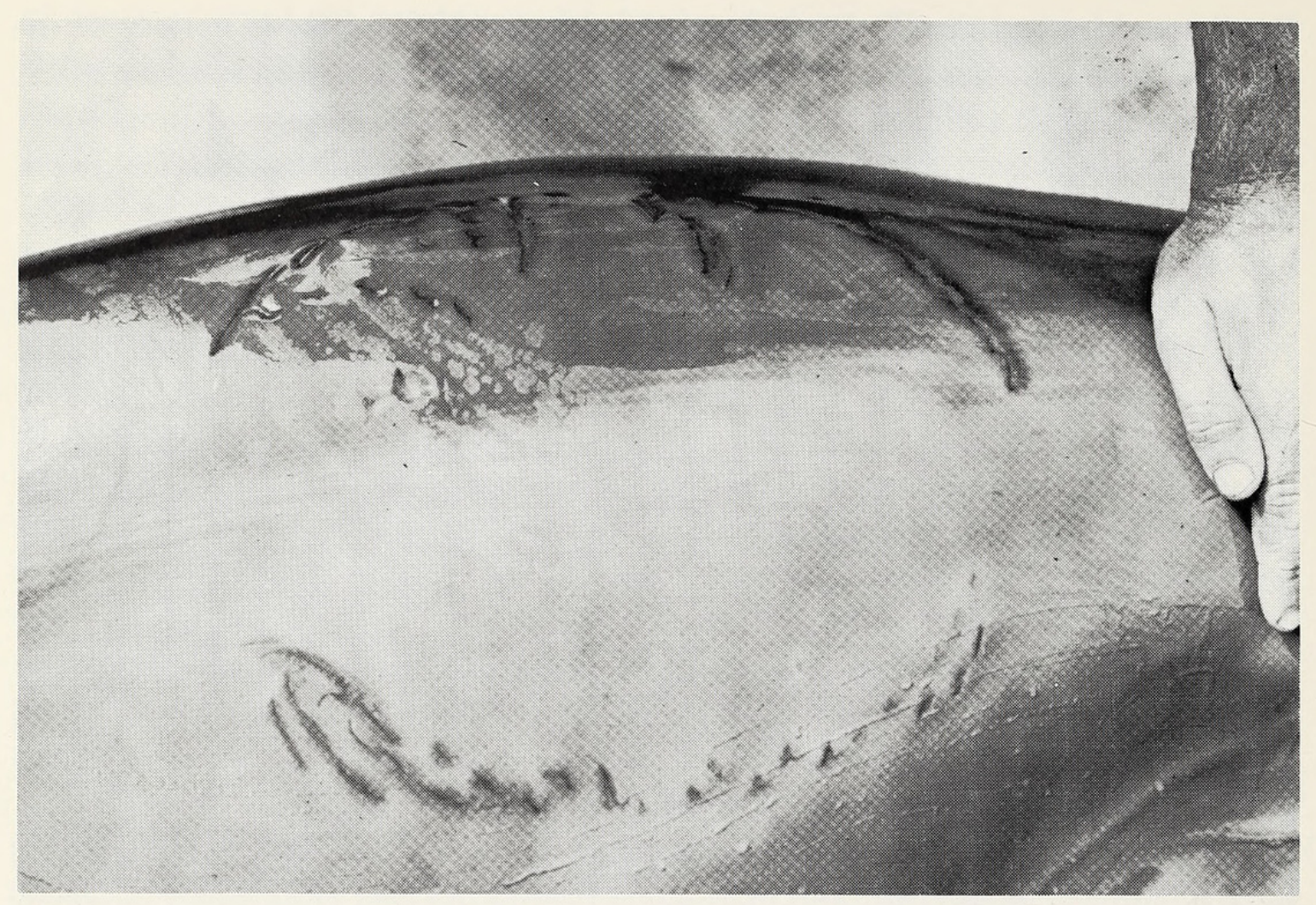

Figure 1. Nearly-healed scar of shark bite on a living Atlantic bottlenosed dolphin, Tursiops truncatus. See text for details.

mens of this barnacle taken from an adult $T$. Truncatus collected on 10 October 1963 at Gulfport, Mississippi. We were told that the infestation on this animal was light.

A young, 12-foot, 8-inch female Cuvier's beaked whale, Ziphius cavirostris Cuvier, that stranded alive near Fort Walton Beach on 10 December 1964 also had an infestation of these barnacles on the posterior upper surface of the caudal flukes, just to the left of center. Apparently this is the first record of this barnacle from this species of cetacean, and the record of the cetacean itself is of interest as it is only the fourth for the Gulf of Mexico (see Gunter, 1954).

$A$ TURSIOps TRUnCatus with a healed shark bite scar: A 6-foot, 3-inch male dolphin captured during early July in water less than five feet deep just off East Pass at Destin had a fresh but nearly-healed scar from the bite of a large shark (Fig. 1). In greatest dimension, the bite measured 103/4 inches wide and $97 / 8$ inches in gape, and was located on the left antero-dorsal side of the body just anterior to a vertical from the left flipper and behind the blowhole. While Gray (1964: 20) stated that Tursiops with evidence of shark bites are not uncommon, one wonders how a shark could successfully attack such a fast-moving and agile animal. However, most sharks are capable of strong bursts of speed and the position of the wound in the case of the Destin dolphin 
suggests that the attacking shark may have been able to attack partly from above and to the side of the dolphin and perhaps was thus able to briefly pin the mammal against the shallow bottom or on one of the many shallow sandy bars in the region where the dolphins are most often found.

With the aid of Dr. Shelton P. Applegate, Los Angeles County Museum, an attempt was made to identify the attacking shark. By a process of elimination based on the size of the bite scar, the arrangement of the teeth and their number and probable shape from the punctures, as well as the known habits and distribution of Gulf of Mexico sharks (see Bigelow and Schroeder, 1948), Dr. Appplegate concluded that the two most likely prospects are the great white shark, Carcharodon carcharias (Linnaeus), and the bull shark, Carcharhinus leucas (Müller and Henle). The bull shark is the most likely prospect of the two because of its abundance and ecological requirements in the northern Gulf of Mexico.

\section{Literature Cited}

Barnard, K. H.

1924. Contributions to the crustacean fauna of South Africa. Annals So. African Mus., 20 (1):1-103.

Beach, Frank A.

1947. Do they follow the leader? Natural History, 56(8):356-359, 379-383.

Bigelow, Henry B., and William C. Schroeder

1948. Sharks. In John Tee-Van, et al., editors, Fishes of the western North Atlantic. New Haven: Mem. Sears Foundation, Bingham Oceanogr. Lab., 1(1) : 59-546.

Brown, David H., and Kenneth S. Norris

1956. Observations of captive and wild cetaceans. J. Mammal., 37(3) :311326.

Brown, David H., Rankin W. McIntyre, C. A. Delli Quadri and Robert J. Schroeder

1960. Health problems of captive dolphins and seals. J. Amer. Veterinary Med. Assn., 137(9):534-538.

Caldwell, David K., Melba C. Caldwell and Dale W. Rice

1965. Behavior of the sperm whale, Physeter catodon L. In K. S. Norris, editor, Whales, dolphins, and porpoises. Proc. 1st Internatl. Symp. on Cetacean Biol., Univ. Calif. Press. To appear in late 1965.

Caldwell, David K., Anthony Inglis and J. B. Siebenaler

1960. Sperm and pigmy sperm whales stranded in the Gulf of Mexico. J. Mammal., 41(1):136-138. 


\section{$2 \mathrm{BHL}$ Biodiversity Heritage Library}

Caldwell, Melba C., Caldwell, David $\mathrm{K}$.

$\uparrow$

, and Siebenaler, J B . 1965. "Observations on captive and wild Atlantic bottlenosed dolphins, Tursiops truncatus, in the northeastern Gulf of Mexico." Contributions in science 91, 1-10. https://doi.org/10.5962/p.241081.

View This Item Online: https://www.biodiversitylibrary.org/item/214245

DOI: https://doi.org/10.5962/p.241081

Permalink: https://www.biodiversitylibrary.org/partpdf/241081

\section{Holding Institution}

Smithsonian Libraries

\section{Sponsored by}

Biodiversity Heritage Library

\section{Copyright \& Reuse}

Copyright Status: In Copyright. Digitized with the permission of the rights holder

Rights Holder: Natural History Museum of Los Angeles County

License: https://creativecommons.org/licenses/by-nc-sa/4.0/

Rights: https://www.biodiversitylibrary.org/permissions/

This document was created from content at the Biodiversity Heritage Library, the world's largest open access digital library for biodiversity literature and archives. Visit BHL at https://www.biodiversitylibrary.org. 